\title{
CRISIS AS A FACTOR OF CYCLICAL DEVELOPMENT
}

\section{Olena Levchuk ${ }^{1}$ \\ Victor Levchuk ${ }^{2}$}

DOI: https://doi.org/10.30525/978-9934-588-15-0-91

\begin{abstract}
Numerous crisis projects have been around for two decades, but, in the present world, they are in crisis, they imagine themselves as natural crisis cases and their causes and consequences. The overwhelming number of other crisis and economic crises, both for the emergence of which remain in its service and for large-scale development are crisis, undoubtedly are systemic, structurally-cyclical, suffering, which requires its vital resources of market economic systems. The prerequisites for the emergence of a financial and economic crisis should include, first, the contradictions in the development of the real and financial sectors of the economy, which are manifested in their asynchrony and disproportionality against the background of constant strengthening. Secondly, it is a crisis of economic policy and economic mechanism based on the principles of monetarism. Third, it is the inconsistency of the principles of the Jamaican world monetary system with the changing conditions of operation and the deployment of forces in the world economy. Financial capital, which is the "shadow" of real capital, in the face of gigantic financial speculation, becomes a fiction and leads to the formation of an unsecured macroeconomic bubble. By 2007, this fictitious capital, or the shadow of its real counterpart, had increased significantly, the illusion of value detached from the real economic reality of prices. This is especially evident in the global financial markets. First-order securities - stocks - have increased their value tenfold. The value of securities, or so-called market capitalization, is ten times the value of real assets, depending on the market situation. According to statistics, by 2008 , global gross domestic product
\end{abstract}

${ }^{1}$ Candidate of Economic Sciences, Associate Professor,

Leading Researcher at the Center for Military Strategic Studies,

National Defence University of Ukraine named after Ivan Chernyakhovsky, Ukraine

ORCID: https://orcid.org/0000-0002-2827-2134

${ }^{2}$ Honored Lawyer of Ukraine, Senior Researcher,

Center of Military and Strategic Research,

National Defense University of Ukraine named after Ivan Chernyahovskyi, Ukraine ORCID: http://orcid.org/0000-0001-6436-985x 
(GDP) was approximately \$50 trillion. And total global financial assets were close to $\$ 200$ trillion, 4 times the real world product. With regard to second-tier securities or derivatives, their volume in the global financial markets exceeded $\$ 500$ trillion. With regard to the peculiarities of the financial crisis in the Ukrainian economy, we believe that special attention should be paid to the causes and consequences of the global financial crisis in our country. In today's context, the new paradigm of state regulation of the financial sector is becoming increasingly relevant - from simply setting the rules of the game and controlling their observance to actively interfering with the processes of buying and selling financial instruments and financial services. Since the financial sphere is one of the important elements of ensuring the economic security of the country, the state becomes a shareholder of financial institutions as a guarantor of their stability not only for the short-term crisis period, but also retains its control after its termination. We are quite convinced that the most active, purposeful and long-lasting state intervention in the economic life of Ukraine is an important condition for ensuring national security at the macroeconomic level.

\section{Introduction}

The basis for the successful functioning of any country in the world is to achieve economic equilibrium, the essence of which is to balance the available resources and needs of society. Reproduction of a social product is a complex overarching process that involves certain elements and is characterized by a defined structure. The tasks and peculiarities of the functioning of individual elements of the reproduction process depend on the forms of ownership, the nature of economic relations and the specific manifestation of economic laws.

The relevance of this study is due to the fact that the viability of the economy of one country and the totality of economies around the world is significantly determined by the activity and efficiency of the reproductive processes. The state of fixed assets, the innovative level of technology and technology, the competitiveness of enterprises and their products depend on them.

The phenomenon of economic crisis is becoming more and more common in the modern vocabulary. Of course, the crisis (or even the likelihood of its occurrence) is a big shock for any country. After all, they cause great harm to national economies and worsen people's well-being. Economic cri- 
ses before the twentieth century limited to one, two or three countries, and then began to acquire international character.

Any large-scale economic crisis is always a serious reason for the next revision of the results of socio-economic processes in the world and in individual countries, while at the same time for rethinking theoretical templates and exaggerated assessments of the possibilities of the economic system.

The most devastating phenomenon that has adversely affected the development of the global economic system during the globalization period was the World Financial Crisis 2007-2009 years by hitting the Ukrainian financial market as well.

The most difficult issue at the moment is to find effective anti-crisis tools that will effectively fulfill the top priority tasks of overcoming the crisis to move the economy into a growth phase.

In today's conditions of globalization, it is of great importance to prevent large-scale financial shocks and to quickly overcome their negative impact if they occur.

\section{The crisis as a factor of cyclical development}

The crisis is the most difficult and controversial phase of the economic cycle. On the one hand, it is associated with destructive forces: declining production, mass bankruptcies, and unemployment, declining living standards, increasing social tensions in society, political tensions, and more.

On the other hand, the crisis has a creative function: cyclical fluctuations in business activity are one of the conditions for economic growth, and the crisis itself is an active part of the creative process. In accelerating the dying out of outdated economic systems, it is at the same time an important link, accelerating the technical and technological renewal of production, structural restructuring of the economy.

The main forming phases determine the nature and duration of the economic cycle, the most tangible in terms of their socio-economic consequences are crisis (recession), contraction, and fall.

The crisis is characterized by:

- Violation of macroeconomic equilibrium, imbalance of the involved structures;

- Excessive production (not supported by the corresponding demand for manufactured products), accumulation of commodities in the wholesale trade; 
- Falling prices;

- Rising unemployment, increasing vacant production capacity;

- The fall in the level of real wages, other incomes, profits of enterprises, living standards of the population;

- Reduction of the effective demand of the population, decrease in the volume of wholesale and retail trade;

- The collapse of monetary ties;

- Gradual increase in the system of mutual non-payments;

- Credit voltage, rising interest rate;

- Lack of money supply, high inflation;

- Massive depreciation of capital, fading of investment processes;

- Stock market fall, stock market panic;

- Massive bankruptcy of enterprises;

- Increasing social tensions in society and so on.

Crisis phenomena continue to increase until the macroeconomic equilibrium is restored to its lowest levels (when the decline process ceases and the depression phase begins). The dual nature of the crisis is manifested in the fact that, on the one hand, it is a consequence of internal contradictions of the system, and on the other - a form of solving them, performing the function of recovery (rehabilitation) of the economic system.

Depression (stagnation, stagnation) can be quite long (shock state). Its main features are:

- Stabilization of production (the lowest level);

- Stops falling prices, slows down inflation processes;

- High unemployment rate remains, the number of jobs remains unchanged; the movement of capital is slow, there are no new investments, the rate of borrowing is high;

- Gradual restoration of business ties; stabilization and reduction of inventory;

- As a result: noticeable gradual spread of resuscitation processes; improving the situation as a whole.

The recovery phase

Main manifestations:

- Start of renewal of fixed capital, modernization of production;

- Renewal of the investment process, activation of aggregate demand;

- Raising the level of production, reducing unemployment; 
- Growth of the loan interest rate, commodity prices.

Stagnation is changing economic growth, the recovery is embracing an increasing number of businesses, industries, sectors of the economy, population incomes and entrepreneurs' incomes are increasing. The pre-crisis state of the economy is recovering.

The economy enters a phase of boom (expansion, boom) and reaches its highest point, the peak of development, the parameters of which are much higher than the previous one. Exaltation is characterized by:

- Massive updating and expansion of fixed capital,

- Reconstruction of old production facilities,

- New construction;

- Increasing national production,

- Active investment process,

- Rapid growth of profits, aggregate demand;

- Rising prices;

- Full employment, a significant increase in wages, increasing shortage of labor, raw materials;

- Development of credit and financial operations, speculative stock games and more.

All this leads to an "overheating" of the economy, an increase in disproportionate phenomena, an increase in the prerequisites for the fall, a new economic cycle, the next turn of socio-economic development of society.

\section{Classification of monetary crises}

In terms of content, monetary crises act as crises in the sphere of monetary circulation and crisis in the sphere of credit. Since money circulation functions to a large extent in the form of credit facilities, monetary crises are in fact crises of the monetary system. They are more often born in the phases of recovery and uplift of the industrial cycle. During the massive renewal of production funds, the demand for credit is rising sharply. This leads to an increase (swell) of corporate debt, an increase in bank interest, an increase in the dummy capital, increases inflation and causes stock market shocks. The monetary crisis begins. The specific phases of its manifestation are the crises of payments, loan capital and money circulation.

The current economic crisis can be attributed to the specific. It has gone beyond one country and is projected to have wide-ranging implications [4, p. 46]. 
The global financial crisis. The current global financial market is a powerful tool for redistributing financial resources. Its main functions include the mobilization of resources and their efficient deployment in sectors of the economy, hedging of currency and financial risks. As a result of the evolution of the financial market, its functions have been transformed, since the main purpose of economic entities is to maximize profits and speed of their receipt.

The current global financial crisis began in 2006 with the crisis in the US high-risk mortgage market and has spread to all countries in the world. When the US Federal Reserve lowered its discount rate to 1\% in 2003 from $6.5 \%$ in 2000 , the oversupply of money led to:

- Rising inflation,

- Formation of excess credit resources,

- Expanding the volume of lending, including mortgage, by commercial banks.

At the same time, the credit boom was accompanied by an increase in the volume and share of high-risk transactions with clients whose solvency was doubtful. Demand and supply in the money market were artificially created, which led to its collapse. In early 2005 , real estate prices fell sharply in the US, UK, and Japan. In mid-2006, prices fell so low that the market value of housing became less than the amount owed to banks for loans for its purchase [2, p. 21].

Effects:

- Mortgage crisis;

- The liquidity crisis that has grown into a large-scale banking crisis; and then into the world financial;

- Actual bankruptcy of industrial enterprises and banking institutions;

- Further nationalization of the largest US mortgage agencies Fannie Mae and Freddie Mac;

- The disappearance of the five largest investment banks - Bear Stearns, Lehman Brothers, Merrill Lynch, Morgan Stanley, Goldman Sachs (actively involved in derivative speculation);

- The purchase by the state of a controlling stake in the world's largest insurance company AIG

- Collapse of a number of mortgage and commercial banks [2, p. 22].

The following are the main causes of the global financial crisis:

- The crisis was the result of unbalanced economic development. The value of derivatives (derivatives) exceeded the value of world GDP by several times; 
- Real estate has become a measure of wealth in the world, so many people have invested in it, and banks and financial companies have lent out to anyone, leading to a crisis in debt and the disappearance of investment banks and mortgage bonds;

- The globalization of economic development, which has led to the rapid spread of the crisis from the US to other countries of the world;

- Deep structural imbalances in the real sector of the economy have shown the problem of overproduction in some sectors of the world economy (excess production capacity and jobs).

\section{Financial crises lead to:}

- Imbalance;

- Recession;

- Default;

- Stock market crashes;

- Political tensions in financial and economic life;

- Cause banking panic among depositors;

- Rising interest rates and business risks.

In general, the global financial crisis is characterized by the collapse of many investment institutions, since it disrupts the equilibrium of the global financial-credit system.

\section{Manifestations of the financial crisis in the countries of the world}

Among the European countries, the crisis most affected:

Great Britain, Spain, Italy, France, Hungary.

The devaluation of national currencies continues, especially in Brazil, Denmark, South Korea, Poland, Russia, Sweden;

China's exports are declining, though the process is paralleling the decline in imports.

A significant drop in GDP during the crisis in most Central and Eastern European (CEE) countries has led to an increase in:

- Risk of social tension,

- Unemployment rate,

- Cases of business stoppage (Poland, Romania, etc.).

- The risk of social tension (significantly increased due to the return to CEE of part of the population (migrants who worked in the West);

- Reduction of money transfers to the above-mentioned countries. 
Thus, in Romania and Bulgaria there was a threat of double unemployment $[1$, p. 56].

The CEE countries have been held hostage to the situation. Government agencies are forced to look for alternative solutions to bring the economy into the growth phase.

It is clear that under such conditions consumption could not be the sole driving force for development. Particular attention should be paid to other important parameters: competitiveness, innovation, infrastructure development, revision of the education and training system.

Significant losses led to the collapse of the stock markets of the world: 2007:

- Securities on the world stock market fell by USD 5 trillion. Investors have shifted their focus away from the stock market to commodity, leading to higher oil and gold prices.

Consequence: rising inflation in almost every country in the world.

2009:

- Industrial production in the European Union (December 2008) fell by $11.5 \%$ year-on-year and by $2.3 \%$ (compared to November 2008),

- In the Euro zone - by $12 \%$ and $2.6 \%$ respectively.

This is an absolute record: no such drop has been observed since 1986 (the beginning of pan-European statistical accounting) [3, p. 37].

\section{China}

On November 20, 2008, Yin Weimin, Minister of Human Resources and Social Welfare, Member of the State Council of the PRC, formally acknowledged the increase in the number of unemployed in the country, calling the situation "critical":

- Export-oriented factories are forced to close;

- Reduction of external demand announces the Chinese government's intentions to reorient the economy to domestic demand. Chinese officials have also announced the planned transfer of their reserves to gold.

For reference. On January 7, 2009, Xinhua, in commenting on the statements of Henry Paulson and Ben Bernanke, laid the blame for the global crisis on the US authorities, accusing them of "excessive emission of dollars when the control agencies were impaired" [4, p. 69]. 
The global financial crisis of 2007-2009 has become the biggest challenge for the world's economy in the age of globalization. Analysts consider it the worst shock since the Great Depression.

\section{Consequences of the crisis for Ukraine}

The Ukrainian economy has felt the main manifestations of the global economic crisis in the fall of 2008 [3, p. 133]:

- Deterioration of a number of economic indicators;

- Problems in the activity of a number of leading commercial banks;

- Reduction of demand for products of ferrous and non-ferrous metallurgy, steel industry;

- Reduction of export and foreign exchange earnings into the national economy.

For reference. The crisis is gradually affecting all industries and other areas, including the investment portfolio. In Kyiv alone, 80 construction projects have been stopped, and the ISD Group has been forced to wind down $\$ 2$ billion worth of enterprise modernization programs [3, p. 33].

\section{Effects:}

- Raising unemployment;

- Labor market imbalances;

- Increasing social tension in society;

- Imbalances in commodity and money markets;

- Increasing the level of economic, business, currency and other major risks;

- The banking sector crisis;

- Lack of financing and arrears (at all levels).

There is an obvious correlation between the amount of money in circulation and the price level: inflation is not possible without a rapid increase in money supply. The rapid growth of the money supply over a short period is accompanied by the corresponding rate of increase in the price level. In the end, the excessive rise in the price level absorbs the economy as a whole. This is due to the change in the growth rate of money supply.

If the growth rate of money supply in circulation slows down, the corresponding reaction of nominal and real GNP and absolute price level can be observed. The lower rate of growth of nominal GNP accordingly influences the real volume of production, and subsequently - the rate of increase of absolute price level [2, p. 25]. 
Thus, a special impact of the crisis on the Ukrainian economy occurred in the period 2008-2009. Excessive borrowing from external capital has led to an increased vulnerability of the economy to the effects of external shocks, which immediately led to the destabilization of Ukraine's financial system as the global export markets worsened and the global credit crisis spread to the countries of Eastern and Central Europe.

\section{The new world economic crisis - forecasts and realities}

Starting in 2016, more and more economists, analysts and experts are predicting a new global financial crisis. Such assumptions are assumed for 2020, but according to the latest data, the World Bank forecasts this phenomenon as early as 2018-2019.

According to analysts, the next financial crisis will have less catastrophic consequences for the world economy than the previous one.

In particular, it is expected that as a result of the US securities market will lose about $20 \%$ of its value, the cost of major energy resources (oil and gas) in the world markets will fall by $35 \%$, and the value of metals (including those that make up the lion's share of Ukrainian exports) $29 \%$ [5].

The World Bank report indicates that global GDP will grow by $3 \%$ in 2018-2019. Bank models show that the likelihood of a worsening economic situation is higher than the possibility of its improvement.

Earlier, the WB had expected a slowdown in world GDP growth, but now economists are talking about a sharp slowdown. In particular, it may be triggered by trade wars (such as between the US and China) triggered by protectionist policies, debt defaults in some of the major emerging markets, and a sharp increase in US monetary policy as interest rates rise.

Geopolitical factors, such as the tense situation on the Korean Peninsula, the Middle East and Russia's relations with the US and Europe, are also at risk, as well as political changes such as the rise of populism, anti-globalization sentiment and "polarization of public opinion."

According to Bloomberg, the main threats will be trade wars between countries, Brexit and the state of world oil prices [6].

The wave of financial crisis at the end of 2019 is almost inevitable for Ukraine as well.

The economy of Ukraine is quite open and therefore dependent on the situation in other countries, so it is possible that everything that 
Ukraine exports to other countries will simply be unnecessary at the end of the year.

No matter when the financial crisis gets hot, Ukraine will face it in an unfavorable environment: with heavy debt and an unstable political situation. Over the past five years, Ukraine has faced huge losses. Billions of dollars went out of the economy through devaluation, tariff hikes and outright looting of savings, which they called "bank cleanup."

The Polish economy has a direct impact on the Ukrainian economy: there are over one million Ukrainians working in the country, who send their home currency. In the case of wage cuts, the consumer and real estate markets will be hit. In addition, commodity prices are falling during the crisis, so Ukrainian exports of grain and metal will be at risk [7].

On the other hand, the economies of the countries that sell raw materials, including Ukraine, can receive surpluses in 2019-2020. It is noted that the shortage in the world oil market and the high demand for metals in the Asian market may cause commodities to rise in price in the near future.

\section{Conclusions}

Today, there is an urgent need to build a sound and effective institutional system of civil society, based on an understanding (by the authorities, economic entities and the population) of collective responsibility for the socio-economic situation in the country.

The current monetary policy strategy is reflected in the implementation of sound, predictable monetary policy. Its main principles are:

- Maintaining a balance between the money supply in circulation and the level of real production (at the level of 3\%);

- Focus on features of long-term cyclicality of economic development;

- Money turnover rate - variable; it changes in line with changes in income, interest rates and other economic parameters;

- The rate of interest is financial, risk-free and time-based leverage, by which the conditions of money circulation affect the output and employment in the economy as a whole. Economic (financial) crises are an integral part of the economic cycle.

Continuous monitoring of the state policy for compliance of the development of national capital and national entrepreneurship, decentralization of economic decision-making will help to increase the efficiency of state 
policy, attract investments and increase the competitiveness of national products, access to foreign markets, etc.

Modern tasks related to realizing potential competitive advantages, stimulating the development of investment-oriented and innovative development require the activation of measures of the state economic policy.

Mechanisms must be put in place to ensure that the state can effectively influence the activities of economic entities (through the use of indirect economic leverage and the implementation of its own business development strategy).

\section{References:}

1. Diakonova I. (2008). Poshuk rozvytku bankivskoi systemy Ukrainy v umovakh hlobalizatsii finansovykh rynkiv [Search for development of Ukrainian banking system in the conditions of globalization of financial markets]. Visnyk $N B U$ [Bulletin of the National Bank of Ukraine], vol. 2, p. 56.

2. Shapovalov A. (2008). Prysutnist inozemnoho kapitalu v bankivskomu sektori Ukrainy [Presence of foreign capital in the banking sector of Ukraine]. Visnyk NBU [Bulletin of the National Bank of Ukraine], vol. 4, pp. 21-25.

3. Zaiets O. (2008). Mizhnarodnyi dosvid, yoho vplyv na bankivsku systemu Ukrainy [International experience, its impact on the banking system of Ukraine]. Visnyk NBU [Bulletin of the National Bank of Ukraine], vol. 7, pp. 33-38.

4. Zaiets O. (2008). Yevropeiskyi dosvid-putivnyk bankivskoi systemy Ukrainy [The European experience is a guide to the banking system of Ukraine]. Visnyk NBU [Bulletin of the National Bank of Ukraine], vol. 8, p. 69.

5. Molokhova Ya.O. (2010). Svitova finansova kryza ta yii naslidky dlia Ukrainy [The global financial crisis and its consequences for Ukraine]. Naukovi pratsi NDFI [Scientific works of NDFI] (electronic journal), vol. 2, pp. 21-27. Available at: http://nbuv.gov.ua/UJRN/Npndfi_2010_2_4

6. Samaieva Yu. (2019). Svitova ekonomichna kryza: shcho robyty y ochikuvaty Ukraini [The global financial crisis: what to expect in Ukraine]. Financial balance (electronic journal). Available at: http://finbalance.com.ua/news/svitova-ekonomichna-kriza-shcho-robiti-ukrani (accessed 22 August 2019).

7. Didenko S. (2019). Novi tryhery finansovo-ekonomichnoi kryzy: hlobalni tendentsii ta yikh vplyv na Ukrainu [New triggers for the financial and economic crisis: global trends and their impact on Ukraine]. Available at: https://ua.news/ua/novi-trygery-finansovo-ekonomichnoyi-kryzy-globalni-tendentsiyi-ta-yih-vplyv-na-ukrayinu/ (accessed 12 June 2019).

8. Teksty.org.ua (2018). Nastupnu finansovu kryzu prohnozuiut na 2020 rik [The next financial crisis is forecast for 2020]. Available at: http://texty.org.ua/ $\mathrm{pg} /$ news/textynewseditor/read/87939/Nastupnu_finansovu_kryzu_prognozujut_u_2020 (accessed 12 September 2019).

9. World Bank (2019). Ukraina - ohliad [Ukraine - Review]. The official representation of the World Bank in Ukraine (electronic journal). Available at: https://www.worldbank.org/uk/country/ukraine/overview (accessed 30 September 2019). 